\title{
PREVALENCE AND AWARENESS OF NOISE INDUCED HEARING LOSS IN TWO FACTORIES IN CALABAR, CROSS RIVER STATE, NIGERIA
}

\author{
ROBERT BASSEY MGBE, ANIEFON N. UMANA, ABIOLA G. ADEKANYE AND MBORA E. OFFIONG
}

(Received 20 April 2017; Revision Accepted 4 July 2017)

\begin{abstract}
Noise above a certain acceptable level or sustained noise may cause damage to the ears. The aim of this study is to determine the prevalence and level of awareness of noise induced hearing loss in Calabar. Seventy-five workers from two noise producing companies, in Calabar- Flour mill and Wartsilla were chosen for this study. An author administered questionnaire was used to record sociodermographic data, occupation, access to ear protection, number of working years, etc; Rhine's test, Webers test, otoscopy and pure tone audiometry were done for each of the participants. Workers in the generator house, loading bay and production plant were regarded as noise exposed workers while others were non-noise exposed. Forty-one of the noise exposed workers in flour mill (66.83\%) had mild hearing loss and ten (16.66\%) had moderate loss. In Wartsilla, twenty six workers $(50.98 \%)$ of the noise exposed workers had mild hearing loss and six $(11.76 \%)$ had moderate loss. Three non- noise exposed workers in each of the companies also had mild hearing loss. $40 \%$ of the participants never heard about ear protection devices; $60 \%$, knew about them. $50 \%$ had seen them and $30 \%$ felt better using them.
\end{abstract}

KEYWORD: Awareness, hearing loss, prevalence, Calabar.

\section{INTRODUCTION}

Noise is sound of irregular frequency. The noise we hear daily may become harmful. When these sounds are too loud even for a brief moment or when they are both loud and long lasting, the can cause noise induced hearing loss (NIHL(Ali et al 2012) Noise induced hearing loss can affect any age or sex. It may be just a threshold shift that is reversible ora permanent loss and this may affect any or both ears(Ali et al 2012, Elias et al 2003, Tenaj et al 2014) Sounds less than $75 \mathrm{~dB}$ even after long exposure are unlikely to cause $\mathrm{NIHL}$ but long or repeated exposure to sound of $85 \mathrm{~dB}$ or above can cause NIHL (Ali et al 2012, Alberto et al 1997) Conversational voice is in the region of $40-50 \mathrm{Db}$. Harmful noise exposure is a daily occurrence in Nigeria and there is so much ignorance about it. In spite of this, the prevalence and awareness of $\mathrm{NIHL}$ and even its prevention have not been adequately addressed hence this paper seeks to address this aspect of hearing loss in our environment. (Ali et al., 2012, Ologe at al 2008, Chidambuka et al 2013)

\section{METHOD}

A total of 75 workers, 65 male and 10 female were randomly selected from wartsilla power generating company out of two hundred and fifteen workers; Another 75 workers 55 males and 20 females were likewise selected from Calabar flour mills out of one hundred and eighty workers. In both companies we had a total of 120 males and 30 females giving a male to female ratio of $4: 1$. Those who work at places with high noise levels like the loading bay, power plant and the production plant were regarded as noise exposed workers and those in such areas as the canteen, offices, staff clinic were regarded as non-noise exposed workers. The noise levels from these noisy areas was measured using a sound level meter (Tetso 815).

An author administered questionnaire was used to record demographic data, occupation, access to ear protection at work, number of working years, etc. Noise mapping of the working environment in the factories was determined using a sound level meter. Rhine's test, Webers test and otoscopy were done on each of the subjects and those with otitis media with effusion, chronic suppurative otitis media, healed perforation and other ear abnormalities were excluded from the study. A pure tone audiometry was done for each of the subjects using a screening audiometer AS208 precalibrated by audiometric calibration system. The average of two readings taken at $9.00 \mathrm{am}$ and $3.00 \mathrm{pm}$ was taken as the final reading. The use of sound proof booth was not possible for logistic reasons. Pure tone audiometry was done in a quiet area with an ambient noise level of 42Db. Personal noise dosimetry was not done. Each participant used about 10 minutes for the audiometry and hearing was categorised according to the WHO classification of hearing loss. Normal hearing $0-25 \mathrm{Db}$; Mild hearing loss 26-40Db; moderate hearing loss 41-

Robert Bassey Mgbe, ENT Department, University of Calabar Teaching Hospital, Calabar. Cross River State, Nigeria. Aniefon N. Umana, ENT Department, University of Calabar Teaching Hospital, Calabar. Cross River State, Nigeria. Abiola G. Adekanye, ENT Department, University of Calabar Teaching Hospital, Calabar. Cross River State, Nigeria. Mbora E. Offiong, ENT Department, University of Calabar Teaching Hospital, Calabar. Cross River State, Nigeria. 
$60 \mathrm{Db}$; Severe hearing loss 61-80Db. Included in this study were those who have put in a minimum of eight years in their respective companies. Data collected was analysed using Epi-info version 6 and results presented in tables. Variables are considered statistically significant if the $p$ value was 0.05 .

\section{RESULTS}

The age range for noise exposed partakers was 22-48 years with a mean of 30 years. The age range for non- noise exposed subjects was 22-60 years with a mean of 41 years. The overall male: female ratio was 4:1 Flour mill had 60 noise exposed workers(80\%) and 15 non-noise exposed workers (20\%). Wartsilla had 51 noise exposed workers (68\%) and 24 non noise exposed workers(32\%). Overall number of noise exposed workers in both factories was 111 representing $74 \%$ of all the workers and non- noise exposed workers 39 i.e $26 \%$. All noise exposed workers in wartsilla were provided with ear protection devices (ear muffs) but only 39 workers $(76.47 \%)$ of the noise exposed workers wore them as specified. The others did not believe the devices made any difference or they did not wear them because of the inconvenience associated with them. At the time of this study, no one in flour mill used any form of ear protection because they were not provided.

Pure tone audiometry results showed, 13 persons in flour mill had a threshold shift at $4000 \mathrm{HZ}$ $(21.66 \%)$ and 6 participants at $6000 \mathrm{HZ}(10 \%)$.

8 participants at wartsilla $(15.8 \%)$ had a threshold shift at $4000 \mathrm{HZ}$ and 2 participants at $6000 \mathrm{HZ}$ $(3.92 \%)$

\section{NOISE LEVELS RECORDED:}

$\begin{array}{ll} & \text { FLOUR MILLS } \\ \text { Power plant } & 87-110 \mathrm{~dB}(105) \\ \text { Production } & 82-106 \mathrm{~dB}(95) \\ \text { Loading bay } & 59-86 \mathrm{~dB}(78) \\ \text { Mechanic workshop } & 55-70 \mathrm{~dB}(62.5) \\ \text { Staff clinic } & 40-50 \mathrm{~dB}(45) \\ \text { Secretariat } & 45-55 \mathrm{~dB}(50)\end{array}$

The highest noise level recorded was $115 \mathrm{Db}$ (power plant) and the lowest was $40 \mathrm{Db}$. The power plant, loading bay, production plant were regarded as noise exposed areas while the staff clinic, secretariat and canteen were taken as non-noise exposed areas. The profile for this exposure at wartsilla showed the same values as those of flour mill..

Forty one $(68.33 \%)$ of the noise exposed group in flour mills had mild hearing loss and ten (16.66\%) were moderate. Twenty-six of these were right sided disorders while sixteen were left sided and nine bilateral. So $85 \%$ of noise exposed workers in flour mill had hearing loss. In Wartsilla, twenty six(50.98\%) of the noise exposed persons had mild hearing loss and six
Power plant

Warehouse

Transport office

Canteen

\author{
WARTSILLA \\ 90-115dB $(110)$ \\ $85-105 \mathrm{~dB}(100)$ \\ $45-55 \mathrm{~dB}(50)$ \\ $42-50 \mathrm{~dB}(46)$
}

workers $(11.76 \%)$ had moderate loss Thirteen were right sided, thirteen left sided and nine bilateral. In all, $(62.74 \%)$ of the noise exposed workers in wartsilla had hearing loss. Three participants $(20 \%)$ in the non-noise exposed group at flour mill had mild hearing loss while three persons $(12.5 \%)$ also in the non- noise exposed group at Wartsilla had hearing loss.

The questionnaires revealed that out of 150 respondents, sixty (40\%) never heard about ear protection, ninety $(60 \%)$ have heard about ear protection, seventy five $(50 \%)$ have used the devise, thirty nine appreciate its benefits, one hundred and eleven $(74 \%)$ are indifferent to its advantages.

Table 1: Distribution of Hearing Loss, Flour Mill.

\begin{tabular}{|l|l|l|l|l|l|}
\hline & Right ear & Left ear & Bilateral & Total & $\%$ \\
\hline Mild & 22 & 13 & 6 & 41 & 68.33 \\
\hline Moderate & 4 & 3 & 3 & 10 & 16.67 \\
& & & & & \\
& & & & & \\
\hline Severe & - & - & - & -- & \\
\hline Profound & - & - & - & - & \\
\hline Total & 26 & 16 & 9 & 51 & 85 \\
\hline
\end{tabular}

Table 2: Distribtion of Hearing Loss, Wartsilla

\begin{tabular}{|l|l|l|l|l|l|}
\hline & Right & Left & Bilateral & Total & $\%$ \\
\hline Mild & 9 & 11 & 6 & 26 & 50.98 \\
\hline Moderate & 4 & 2 & 0 & 6 & 11.73 \\
\hline Severe & - & - & - & - & - \\
\hline Profound & - & - & - & - & - \\
\hline Total & 13 & 13 & 6 & 32 & 62 \\
\hline
\end{tabular}




\section{DISCUSSION}

At flour mill Calabar, noise was essentially generated from the electrical and production plants while Wartsilla mainly generated noise from the power house. In both places the sound level exceeded the threshold of $90 \mathrm{~dB} .85 \%$ of the workers in flour mill and $62.74 \%$ of those in wartsilla had hearing loss. This study has shown a high prevalence of hearing loss in the noise exposed workers compared to the non noise exposed workers and the difference between the two groups is significant. The prevalence of niose induced hearing loss in flour mill was $85 \%$ and at wartsilla, $62.74 \%$. These rates are comparable to those found by other investigators in Nigeria, Malasia, India. (Tenaj et al 2014, Ahmad et al 2013, Omokhodion et al 2009)The difference observed between wartslla and flour mill may be attributed to the use of ear protection by some of the wartsilla workers; besides wartsilla has been around for only fifteen years whereas flour mills is more than 40 years in existence. The workers are exposed to longer years of noise. The reason is because damage to hearing may occur following very loud sound for a moment or sound above a particular decibel for a long period of time. Hearing loss may show up in the first ten year but may commence as early as $5-9$ years.(Ali et al 2012 , Oleru et al 1980)thus the difference in prevalence rate of hearing loss. The degree of hearing loss ranged from mild to moderate degrees only. Based on the WHO classification of hearing loss there was no instance of severe or profound hearing loss. This finding agrees with those of Ologe et al (Ologe et al 2008, Omokhodion et al 2009, Alberto et al 1997).

Of the noise exposed workers in flour mill, twenty six (44.33\%) had right sided loss, sixteen $(26.66 \%)$ had left sided loss, nine had bilateral loss. Out of the fifty-one people, forty one $(68.33 \%)$ had mild hearing loss and ten (16.77\%) had moderate loss. In wartsilla, thirteen people $(25.49 \%)$ had right sided loss, thirteen $(25.49 \%)$ had left sided loss and six (11.76\%), bilateral loss. Out of the thirty two people, twenty six $(50.98 \%)$ had mild loss and six of them, $(11.76 \%)$ had moderate loss.

In the non- noise exposed group, three workers in flour mill $(20 \%)$ and three in warsilla $(12.5 \%)$ had mild loss. This is the level of hearing loss that is not easily noticeable and most people are not aware of it because there are no avenues for routine hearing checks.

This study agrees with findings of Ali et al that unilateral loss occurs as part of NHIL even though the standard definition of NHIL involves both ears (Ali et al 2012). The right side was affected more than the left in this study. Many workers have found that males are more affected than females, (Omokhodion et al)likewise in this study most of the workers are males besides, no female happened to be in the noise exposed areas.

The average threshold shift for noise induced hearing loss is at $4 \mathrm{Khz}$. This is an early indicator but is not pathognomonic for NIHL since it may also be found in response to ototoxic drugs.(Alberto et al 1997)In all, we had twenty one partakers with threshold shift of $4 \mathrm{Khz}$ and eight of them at $6 \mathrm{Khz}$. In Brazil, De carvalho et al in their audiometric tests for NIHL considered 3, 4, and $6 \mathrm{Khz}$ frequencies as hearing threshold averages for they were the most affected by NHIL. (De carvalho et al)
In this study, of the one hundred and fifty participants, sixty (40\%) never heard about ear protection devices; Ninety respondents (60\%) knew about them. Seventy five $(50 \%)$ had seen them out of which $(30 \%)$ felt better using ear protection while sixty $(40 \%)$ were indifferent to its use. This low response to the use of something beneficial i.e. ear protection may not be unconnected with their low level of awareness. This is even lower than the finding of Gunderson et el working with employees of urban music clubs. Only $16 \%$ used the ear protection devise regularly(Gunderson et al 1997)

\section{CONCLUSION}

There is no doubt that excessive noise can be harmful to the ears. In Nigeria and in most of sub Saharan Africa, there is much ignorance concerning the harmful effects of noise. It is imperative that government should embark on intensive enlightenment programmes, education and also legislations guiding pre-employment, working and post- employment screening for hearing. Enforcement of ear protection devises for all noise exposed workers is important. This will detect cases of hearing loss very early and enable something to be done at that stage before it becomes incapacitating.

\section{REFERENCES}

Ahmad, F. I., Aziah, D., Zaliha, I and Baharudin, A., 2013. Noise Induced Hearing Loss Among Quarry Workers in A North Eastern State of Malasia. A Study On Knowledge Attitude And Practice: Oman med J (5) 331-336.

Ali, A., Grandawa, I., Nwawolo, C and Somefun, O., 2012. Noise induced Hearing loss in a cement company in Nigeria. Online journal of medicine and medical science, 1, (3): 49-54.

Alberto, P. W., 1997. Noise And The Ear In Scott Brown's Otolaryngology, Adult audiology. Butterworth Heinemann. 2 (11): 1-34.

Ayodele, O., Oyewumi Adebumi Sunmonu M., Occupational Exposure to Noise And Patterns Of Hearing Thresholds Among Factory Workers in Ibadan-Nigeria.

Chidambuka, A., Musasa, F and Muleti, S., 2013. Prevalence of NIHL Among Employees At A Mining Industry in Zimbabwe. Africa Health Sciences: 13, (4): 899-906.

De Carvalho, A. C. F., Crispin, K. G. M and Ferreira, A.

P., Incidence And Prevalence Of Noise Induced Hearing Loss Of Workers In A Metallurgical Company In Manaus-Brazil.

Elias, S. O and Ijaduola, G. T. A., 2003. Noise Induced Hearing Loss in laundry workers in Lagos. Nigerian medical practitioner. 44, (1): 3-6.

Eziyi et al., Knowledge Attitude And Practice of Sawmill Workers In Osun State Nigeria. Niger J Health Sci. (15): 36-9. 
Gunderson, E., Moline, J and Catalano, P., 1997. Risk of Developing Noise Induced Hearing Loss In employees Of Urban Music Clubs. Am J. Ind Med 31, (1): 75-79.

Gupta, M., Khajuria, V., Manchas, K. L and Singh, O.,

2015. Pattern Of Noise Induced Hearing Loss And Its Relation With Duration Of Exposure To Traffic Police Personnel. Indian Journal Of Community Health. 27, (2):

Ighoroje, A., Marchie, C and Nwobodo, E. D., 2004. Noise Induced Hearing As An Occupational Risk Factor Among Traders. Nigerian Journal Of Physiological Sciences. 19, (4): 14-19.

Kuyawa, S. G and Liberman, M. S., 2009. Adding Insult To Injury. Cochlear Nerve Degeneration After Temporary Noise Induced Hearing Loss. J Neurosci 29, (45): 14077-14085.

Oleru, U. G., 1980. Comparism of Hearing of Nigerian Textile Workers And A Control Group. Am. Ind. Hygiene Association J., 41, 283-287.

Ologe, F. E., Olajide, T. G., Nwawolo, C. C and Oyebola, B. A., 2008. Deterioration Of Noies Induced Hearing Loss Among Bottling Factory Workers. J laryngo otol, (8): 786-794.
Omokhodion, F. O and Adeosun, A. A., 2009. Hearing Impairment Among Mill Workers In Small Scale Enterprises In South West Nigeria. Dept. of Comm. Health; Dept. of ORL UCH Monthly Inter disciplinary journal. 9, (36): 75-77.

Tenaj, M. K., 2014. Noise induced Hearing loss. Indian J Otol. 20:151-4.

World Health Organization., 1997. Prevention Of Noise Induced Hearing Loss Report Of WHO-PDH. Informal Consultation Held At The WHO, Geneva On The $28^{\text {th }} 30^{\text {th }}$ October; Strategies In The Prevention Of Deafness And Haring Impairment Series 3 WHO/PDH/98.5 google scholar. 
QUESTIONNAIRE

CONCENT FORM

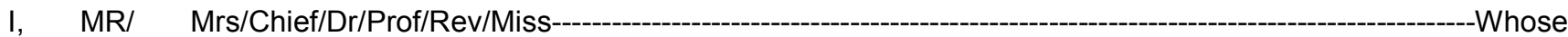

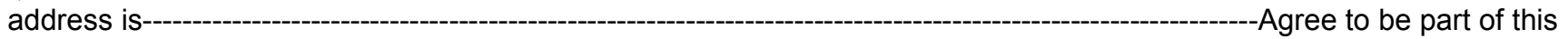
research, Prevalence and awareness of noise induced hearing loss in two factories in Calabar, Cross river state.

Sign/Thumb print:

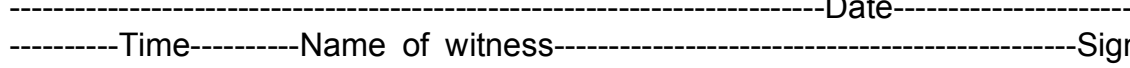

Date.

Name:

Age:

Sex:

Address:

Occupation:

Workplace:

Job description:

No of years at work:

Any knowledge about ear protection?

Source of knowledge: workplace/Radio/Television/Before employment.

Do you think ear protection devices can help you?

Do you desire an ear protection device?

What would you have loved to change in your work place? 